\title{
Microstructural evolution of cement pastes blended with two types of volcanic materials
}

\author{
Evolución microestructural de pastas de cemento adicionadas con dos tipos de materiales \\ volcánicos
}

Diana M. Burgos (Main and Corresponding Author)

Grupo de Materiales Compuestos (GMC)

Universidad del Valle

Calle 13 \# 100-00 - Cali (Colombia)

diana.burgos@correounivalle.edu.co

\section{Luisa M. Cardona}

Escuela de Ingeniería de Materiales

Universidad del Valle

Calle 13 \# 100-00 - Cali (Colombia)

\section{Álvaro Guzmán}

Escuela Colombiana de Ingeniería Julio Garavito AK 45 No. 20559 (Autopista Norte) - Bogotá (Colombia)

alvaro.guzman@escuelaing.edu.co

\section{Khandaker M. Anwar Hossain}

Department of Civil Engineering, Ryerson University, 350 Victoria Street, ON M5B 2K3 - Toronto (Canada)

ahossain@ryerson.ca

\section{Silvio Delvasto}

Grupo de Materiales Compuestos (GMC)

Universidad del Valle

Calle 13 \# 100-00 - Cali (Colombia)

silvio.delvasto@correounivalle.edu.co

Manuscript Code: 797

Date of Acceptance/Reception: 16.11.2017/27.08.2016

DOI: 10.7764/RDLC.16.3.447

\section{Abstract}

This article presents results of a research about the effect to incorporate Colombian volcanic materials as a replacement of ordinary Portland cement on its hydration process. For this particular case were used Tolima volcanic material (TVM) and Puracé volcanic material (PVM). Pastes with 100\% ordinary Portland cement and blended cement pastes containing $20 \%$ by of weight volcanic materials were prepared. The monitoring and identification of the hydration characteristics were carried out using Fourier-transform infrared spectroscopy (FTIR), thermogravimetric analysis (TG/DTG) and scanning electron microscopy (SEM) at 7, 28, 90 and 360 curing days. The results indicated that the main phases of the blended cement pastes containing PVM were ettringite and calcium silicate hydrate (CSH), which confirmed the pozzolanic activity of this material. The blended cement pastes containing TVM exhibited no significant differences in hydration products compared to the reference pastes, due to its inert nature.

Key words: Volcanic materials, blended cements, hydration products, pozzolanic reactivity.

\section{Resumen}

En este artículo se presenta un análisis del efecto de incorporación de los materiales volcánicos de Tolima (MVT) y Puracé (MVP) en el proceso de hidratación de pastas de cementicias. En este sentido, se prepararon pastas de $100 \%$ cemento Portland ordinario y pastas adicionadas con los materiales volcánicos como remplazo del 20\% en peso del cemento. El seguimiento e identificación de las reacciones de hidratación se determinaron mediante el método de espectroscopia infrarroja por transformada de Fourier (FTIR), análisis termogravimétrico (TG/DTG) y microscopía electrónica de barrido (MEB) a 7, 28, 90 y 360 días de curado. Los resultados demostraron que las fases principales de las pastas adicionadas con MVP fueron la etringita y silicato cálcico hidratado, este último confirmó la actividad puzolánica de este material; mientras que en el caso de las pastas adicionadas con MVT no se observaron diferencias significativas en los productos de hidratación respecto a las pastas de referencia o patrón, debido a su naturaleza inerte. 
The use of natural pozzolans dates back to ancient times, and continues to be of great importance to the cement and construction industry, mainly because of the high availability of these pozzolans worldwide and their easy incorporation into production processes. Natural pozzolans are used in mortars, concretes, and as components of blended cements. Volcanic materials are a type of natural pozzolan formed during volcanic eruptions; depending on the nature of the explosions and cooling conditions, different types of materials composed mainly of $\mathrm{SiO}_{2}, \mathrm{Al}_{2} \mathrm{O}_{3}$ and $\mathrm{Fe}_{2} \mathrm{O}_{3}$ are generated (Massazza, 1993). In a volcanic eruption, it is possible for the finest particles can be dragged, forming a thin layer of ash in the vicinity of the volcano. This is known as "ash fall". In addition, if liquid magma is sprayed or violently thrown, the particles will solidify in the air as small volcanic glass fragments; however, if the eruption expels large quantities of magma and ash, these tend to cemented together to form a solid rock called "tuff" (Siddique, 2011). The reactivity of these materials is mainly related to their amorphous structure that arises from the cooling conditions; it is also related to the physical structure of the particles and the potential to react and form cementitious compounds (Kirk \& Zuleta, 2000). The importance of using volcanic materials in the cement industry requires a comprehensive assessment of the effect of their addition on the microstructure of cement, which controls the properties of mortars and hardened concrete. In this regard, several researchers have shown that volcanic materials can be used in mortars for structural rehabilitation of existing buildings (Pavlidou, 2011; Balog, Cobîrzan, Aciu, \& Iluţiu-Varvara, 2014). Additionally, it has been demonstrated that the incorporation of volcanic materials in the production of cement produces several advantages, such as hydration heat reduction (Rahhal \& Talero, 2009); reduction of the energy required to produce one ton of binder by partially replacing cement with volcanic materials (Hamidi, Kacimi, Cyr \& Clastres, 2013); and increased strength of the cement when exposed to different aggressive agents (Uzal \& Turanli, 2003). There are approximately 29 volcanoes in Colombia, and among the most active ones are Nevado del Tolima and the Puracé volcano (Figure 1). By considering above and the fact that there are many active volcanoes in Colombia, which have generated huge sources of volcanic materials throughout the times, this research job proposes evaluate the microstructural evolution of cement pastes blended with two types of volcanic materials and in this way to explore the possibility of using local materials as sources of cement addition for the production of special concretes and mortars in the region.

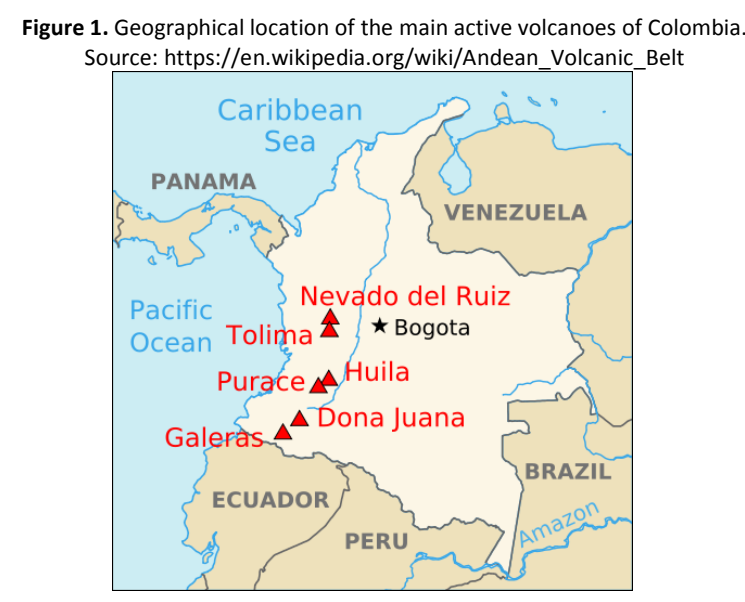

Experimental methodology

\section{Materials}

Samples were taken from two deposits of volcanic material located in the Departments of Cauca and Tolima; these deposits are located at the foothills of the Puracé volcano and the Nevado del Tolima volcano. Physical and chemical properties of TVM and PVM are compared with the Portland cement in Table 1 . Chemical analysis indicated that the sum of $\mathrm{SiO}_{2}, \mathrm{Al}_{2} \mathrm{O}_{3}$ and $\mathrm{Fe}_{2} \mathrm{O}_{3}$ for TVM and PVM exceeds the limits established by the standard ASTM C618-12 (ASTM, 2012) for natural pozzolans ( $70 \%$ by mass). It should also be noted that this standard does not specify the structure nor the morphology of these compounds (Çavdar \& Yetgin, 2007). The PVM composition is acidic because its $\mathrm{SiO}_{2}$ content is greater than 65\%, whereas the TVM composition is intermediate because its $\mathrm{SiO}_{2}$ content is between $55 \%$ and $65 \%$. Accordingly, both materials may have a strong affinity for lime in the presence of water at room temperature (Valdez, Das, \& Rivera, 2004). The amount of oxides of sodium and potassium known as "alkalis" is found to be higher in TVM $(6.87 \%)$ than that in PVM $(0.07 \%)$ and that in Portland cement (2.6\% maximum). Higher alkali presence in the TVM may have deleterious effects leading to disintegration of concrete due to alkali-silica reaction (Hossain, 2005). TVM and PVM have an average particle size close to $21 \mu \mathrm{m}$. The percentage of loss on ignition of both materials (8.35\% for PVM and $0.4 \%$ for TVM) are within the established limit for natural pozzolans under the standard ASTM C618-12 (ASTM, 2012) 
( $\approx 10 \%)$. The difference between loss on ignition values arises mainly due to PVM is composed of elemental sulfur and other sulfur compounds that are highly volatiles (Burgos et al., 2015). Table 1 also shows the characteristics of Portland cement type III, which was used as the reference material and is principally composed of calcium oxide (64\%).

\begin{tabular}{|c|c|c|c|}
\hline Characteristics & $\begin{array}{c}\text { Portland } \\
\text { cement type III }\end{array}$ & TVM & PVM \\
\hline \multicolumn{4}{|c|}{ Chemical composition (\%) } \\
\hline $\mathrm{SiO}_{2}$ & 21.70 & 64.36 & 87.45 \\
\hline$S$ & 1.02 & 0.00 & 0.04 \\
\hline $\mathrm{Fe}_{2} \mathrm{O}_{3}$ & 4.39 & 4.92 & 1.89 \\
\hline $\mathrm{TiO}_{2}$ & 0.31 & 0.54 & 1.16 \\
\hline $\mathrm{Al}_{2} \mathrm{O}_{3}$ & 5.44 & 15.90 & 0.23 \\
\hline $\mathrm{Ba}$ & 0.00 & 0.08 & 0.13 \\
\hline $\mathrm{CaO}$ & 63.99 & 4.71 & 0.07 \\
\hline $\mathrm{Na}_{2} \mathrm{O}$ & 0.31 & 5.38 & 0.05 \\
\hline MgO & 1.52 & 1.80 & 0.05 \\
\hline $\mathrm{P}_{2} \mathrm{O}_{5}$ & 0.18 & 0.17 & 0.03 \\
\hline $\mathrm{K}_{2} \mathrm{O}$ & 0.30 & 1.49 & 0.02 \\
\hline $\mathrm{Zr}$ & 0.14 & 0.01 & 0.02 \\
\hline $\mathrm{Cr}$ & 0.00 & 0.00 & 0.01 \\
\hline $\mathrm{Cu}$ & 0.00 & 0.00 & 0.01 \\
\hline $\mathrm{Sr}$ & 0.14 & 0.09 & 0.00 \\
\hline Loss on ignition (\%) & 0.60 & 0.40 & 8.35 \\
\hline Density $\left(\mathrm{g} / \mathrm{cm}^{3}\right)$ & 3.10 & 2.09 & 2.18 \\
\hline $\begin{array}{l}\text { Average particle } \\
\text { size }(\mu \mathrm{m})\end{array}$ & 21.08 & 20.20 & 21.00 \\
\hline
\end{tabular}

The SEM images in Figure 2 provide insight of the morphology of the volcanic materials particles. TVM have irregular and sharp-edged grains, the particle surface shows low vesicularity and high density, resulting in lower water demand for cementitious pastes. Other typical hydromagmatic feature of the TVM is a peculiar stepped surface related to the brittle-mode fragmentation that occurs during an explosive magma- water interaction (Roverato, Capra \& Sulpizio, 2013). PVM has roundish grains with rough surfaces capable of absorbing a considerable amount of water in cementitious pastes. This surface is typical of a dense glass pyroclast.

Figure 2. SEM micrographs (6000X) of the volcanic materials studied: a) TVM and b) PVM. Source: Burgos (2016).
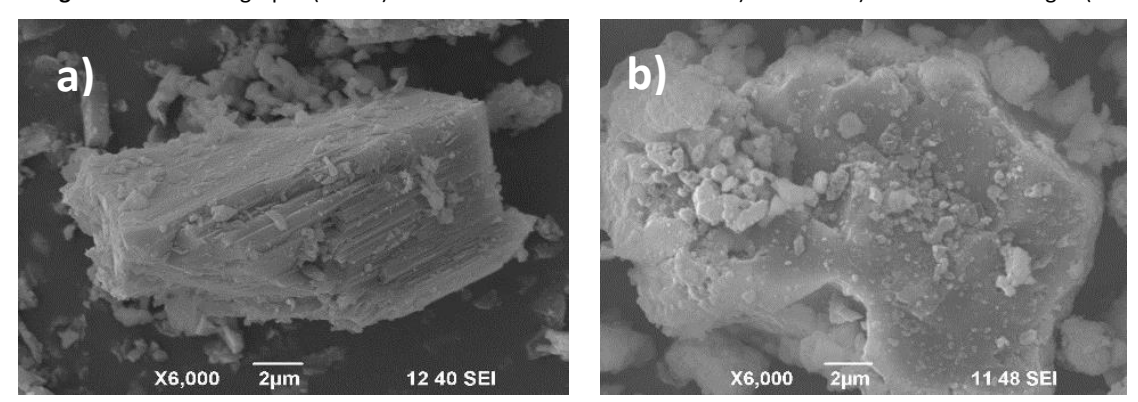

Figure 3 presents micrographs of thin sections of the volcanic materials. The petrographic study indicated that PVM is composed primarily of an amorphous volcanic glass phase and occasional opaque crystals dispersed in the vitreous matrix. The petrographic study of TVM indicated that this material is composed of scattered tabular plagioclase phenocrysts, and crystals of subhedral quartz of smaller size floating in a hypocrystalline matrix without preferential orientation. These observations confirm the observations drawn from the SEM analysis and by a study done about the grindability of the materials that show that the particle size of PVM decreased faster than the PVM when they were ground under the same conditions of milling. It is known that a crystalline material is easier to grind than an amorphous.

Figure 4 shows the qualitative XRD test results of the volcanic materials. The diffraction pattern of TVM confirms the results of the previous petrographic study. TVM is a predominantly crystalline material composed mainly of albite, with a high intensity peak at $2 \theta \approx 28.059^{\circ}$ and peaks of lesser intensity that correspond to anorthite and andesine, minerals known as plagioclases, and accessory minerals such as zeolite, quartz, cordierite and diopside. Furthermore, the 
diffraction pattern of PVM exhibited a high intensity peak that corresponds to alpha cristobalite with a diffraction angle of $21.9361^{\circ}$, a phase that crystallizes at high temperatures and faster than quartz (Prado et al., 2007). Other peaks of lesser intensity corresponding to albite, zeolite and sulfur $S_{8}$ are present as well. The presence of sulfur $S_{8}$ indicates that the PVM comes from a region with high flow of sulfur-rich hydrothermal fluids.
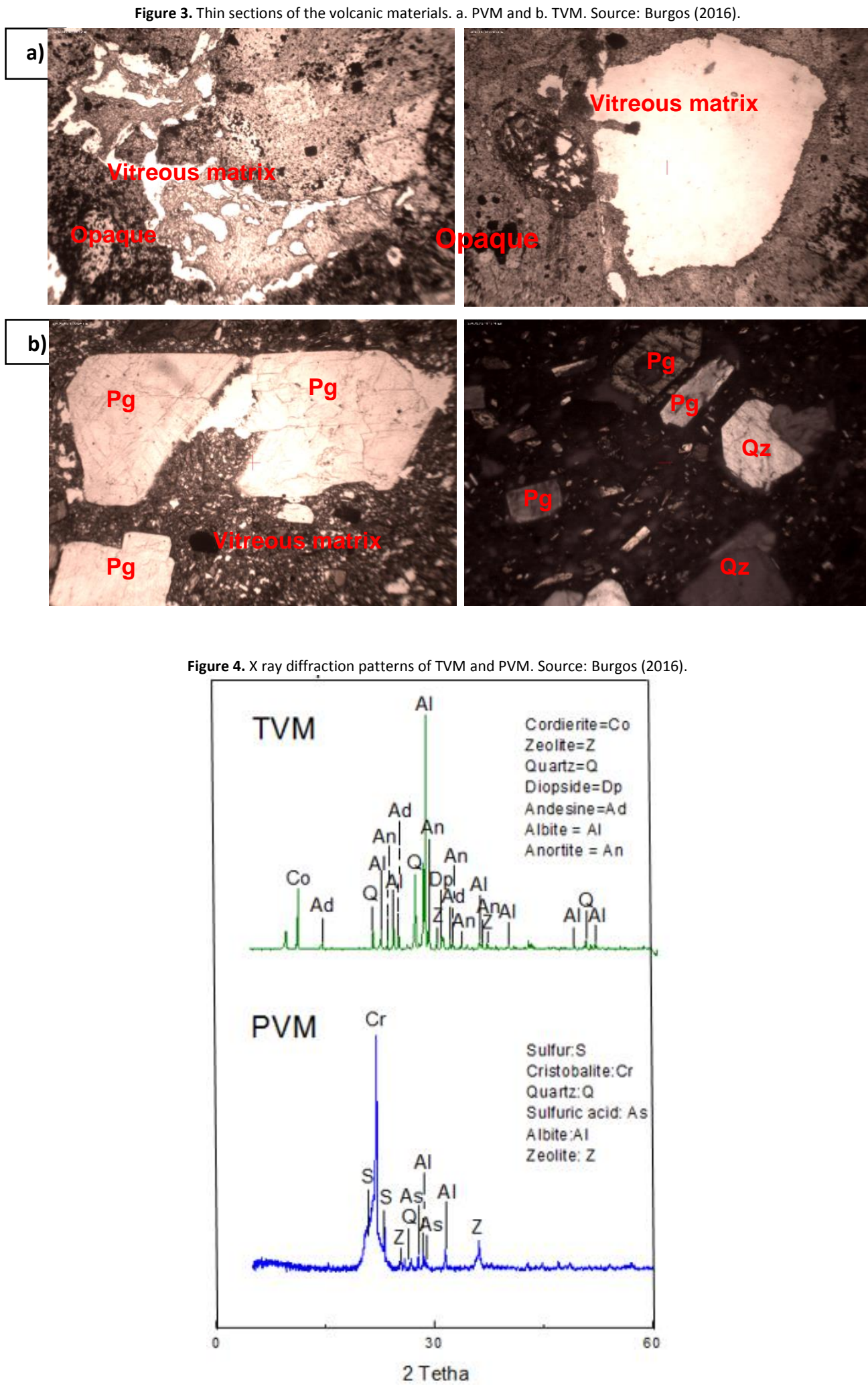

\section{Mixture preparation and experimental procedure}

For evaluate the influence of TVM and PVM on the hydration process, cement pastes with Portland cement type III without any additions and blended cement pastes containing $20 \%$ of TVM (by weight) and 20\% of PVM (by weight), 
were prepared. These proportions were selected in preliminary studies (Burgos, 2016). A water/binder ratio of 0.3 was used for reference pastes and blended cement pastes with TVM; whereas the blended cement pastes with PVM required a water/binder ratio of 0.35 to achieve good workability characteristics. The water/binder ratio in cement pastes was measured using the flow table (ASTM C230; ASTM, 2014) in order to achive similar consistency in all samples. The samples were cured at room temperature and $100 \% \mathrm{RH}$ for curing periods of 7, 28, 90 and 360 days. Once each period was completed, the pastes were dried and ground, and finally "frozen" using acetone and ethanol to prevent the continuation of the hydration process. Lastly, the microstructure of the samples were evaluated using techniques as Fourier-transform infrared spectroscopy (FTIR), thermogravimetric analysis (TG) and scanning electron microscopy (SEM).

\section{Results and discussion}

\section{Hydration study by Fourier-transform infrared spectroscopy (FTIR)}

Figure 5 shows the IR spectra (obtained in $\mathrm{KBr}$ pellets) of the reference cement pastes and blended cement pastes with TVM and PVM, registered at 7, 28, 90 and 360 curing days. In general, 8 bands can be detected in each of the IR spectra as follows:

- Band 1 (at wavelengths between 3640 and $3644 \mathrm{~cm}^{-1}$ ) corresponds to the ${ }^{-} \mathrm{OH}$ group from calcium hydroxide $\mathrm{Ca}(\mathrm{OH})_{2}$.

- Band 2 (at wavelengths close to $3457 \mathrm{~cm}^{-1}$ ) corresponds to ${ }^{-} \mathrm{OH}$ groups of the water linked to different hydration compounds of the cement pastes.

- Band 3 (at wavelengths between 1640 and $1650 \mathrm{~cm}^{-1}$ ) corresponds to the stretching and bending vibrations of water linked to sulfates present in the binder.

- Band 4 (at wavelengths between 1400 and $1500 \mathrm{~cm}^{-1}$ ) corresponds to compounds associated with $\mathrm{CO}_{3}$ such as carbonates.

- Band 5 (at wavelengths between 1011 and $1200 \mathrm{~cm}^{-1}$ ) corresponds to stretching vibration of sulfate ion.

- Band 6 (at wavelengths between 990 and $1100 \mathrm{~cm}^{-1}$ ) corresponds to the main characteristic peaks of polymerized silica from the $\mathrm{C}-\mathrm{S}-\mathrm{H}$.

- Band 7 (at a wavelength of $877 \mathrm{~cm}^{-1}$ ) corresponds to compounds associated with $\mathrm{CO}_{3}$.

- Band 8 (at wavelengths close to $656 \mathrm{~cm}^{-1}$ ) correspond to $\mathrm{SiO}_{4}$ compounds.

Figure 5 a) indicates that at early curing ages ( 7 days), band 1, which is indicative of $\mathrm{Ca}(\mathrm{OH})_{2}$, for the blended cement pastes with TVM does not exhibit a difference in intensity compared to the reference sample, whereas the blended cement pastes with PVM exhibits a reduction in the intensity of this peak compared to the intensity of the other two samples. This difference is related to the behavior of bands 6 and 8 that correspond to the main characteristic peaks of $\mathrm{CSH}$ gel and the vibration of the $\mathrm{Si}_{-} \mathrm{O}_{4}$ bond, respectively. It is noted that blended cement pastes with TVM behave similarly to the reference sample. While, in blended cement pastes with PVM, this band tends to move slightly to higher frequencies compared to the other two samples, which would suggest the polymerization of the silicate tetrahedrons to form the CSH gel. The production of this gel is due to the affinity of PVM with the $\mathrm{Ca}(\mathrm{OH})_{2}$ produced by the hydration of cement. In addition, it is noted that the incorporation of the PVM significantly changed the band 5, which corresponds to the S-O vibration associated with the formation of ettringite. This increase could correspond to the high content of sulfur compounds in the PVM, represented as a large loss on ignition in Table 1. The PVM comes from a region with a high circulation of sulfur-rich hydrothermal fluids, providing more of these compounds to the hydration reactions and therefore increasing the formation of ettringite at early curing ages. This analysis confirms the reports from Burgos et al. $(2014,2015)$, who demonstrated that TVM is an inert material, that their fine particles act as micro-fillers that fill the pores between the cement particles causing better dispersion of cement grains and promotes the formation of hydration products very similar to the reference sample. In contrast, as a natural pozzolan, the PVM generates reactions that allow the formation of new hydration products. Figures $5 \mathrm{~b}$ ), c) and d) show the microstructural evolution of the cement pastes over time at 28,90 and 360 curing days, respectively. Depending on the bond strength, the absorption bands can shift to a higher frequency with the time and consequent development of hydration reactions (Delgado, 2006; Puertas et al., (2012). In general, and as expected with the curing time, the spectra of the reference sample and the blended cement pastes with TVM exhibits intensity changes, related with the normal progress of the hydration process. Whereas, the spectra of blended cement with PVM exhibits clear changes, including the suppression or even the possible disappearance of band 1 and band 8, which indicates the consumption of $\mathrm{Ca}(\mathrm{OH})_{2}$ and silica $(\mathrm{SiO})_{4}$ during curing time due to the evolution of the pozzolanic reaction. Consequently, displacement to higher frequencies and increment in the intensity of band 6 corresponding to the CSH (Hidalgo et al., 2007), were observed. On the other hand, the band 2 (corresponding to the $\mathrm{O}-\mathrm{H}$ vibration) increased in width and intensity with the progress of the reactions and the curing time. 
In general, in all cement pastes (being most obvious in the blended cement pastes with PVM), it is noted that band 5 (corresponding to ettringite) tends to diminish gradually with increasing curing time. This effect is attributed to the ettringite which in turn reacts further with the aluminate and ferrite phases to form monosulfatos (Bonavetti \& Rahal, 2006). The investigation by Bhat $\&$ Debnath (2011) demonstrates that this region is sensitive to the hydration process and that crystallization of sulfates occurs at an early stage and will remain as inactive phases, thus diminishing the intensity over time. Regarding bands 4 and 7 (corresponding to $\mathrm{CO}_{3}$ compounds) it is noted that the reference pastes has the highest intensity at these peaks compared to the blended cements with volcanic materials. This could be due to the calcium carbonate formed during the clinker calcination (Trezza \& Lavat, 2001) or by the atmospheric reaction of $\mathrm{CO}_{2}$ with the calcium hydroxide that produces the precipitation of $\mathrm{CaCO}_{3}$ (Bhat \& Debnath, 2011). The last may occur during the processes of curing or during the preparation of test samples. The blended cement pastes with volcanic materials did not show carbonation signals, because the density of the pastes with additions increases, therefore the carbonation process is hindered (Heikal, Abd El Aleem, \& Morsi, 2013); or because more stable phases are formed during the hydration process (Ylmén, Jäglid, Steenari, \& Panas, 2009).

Figure 5. FTIR graphs for reference cement pastes and blended cement pastes with TVM and PVM: a) 7 curing days, b) 28 curing days, c) 90 curing days and d) 360 curing days. Source: Burgos (2016).

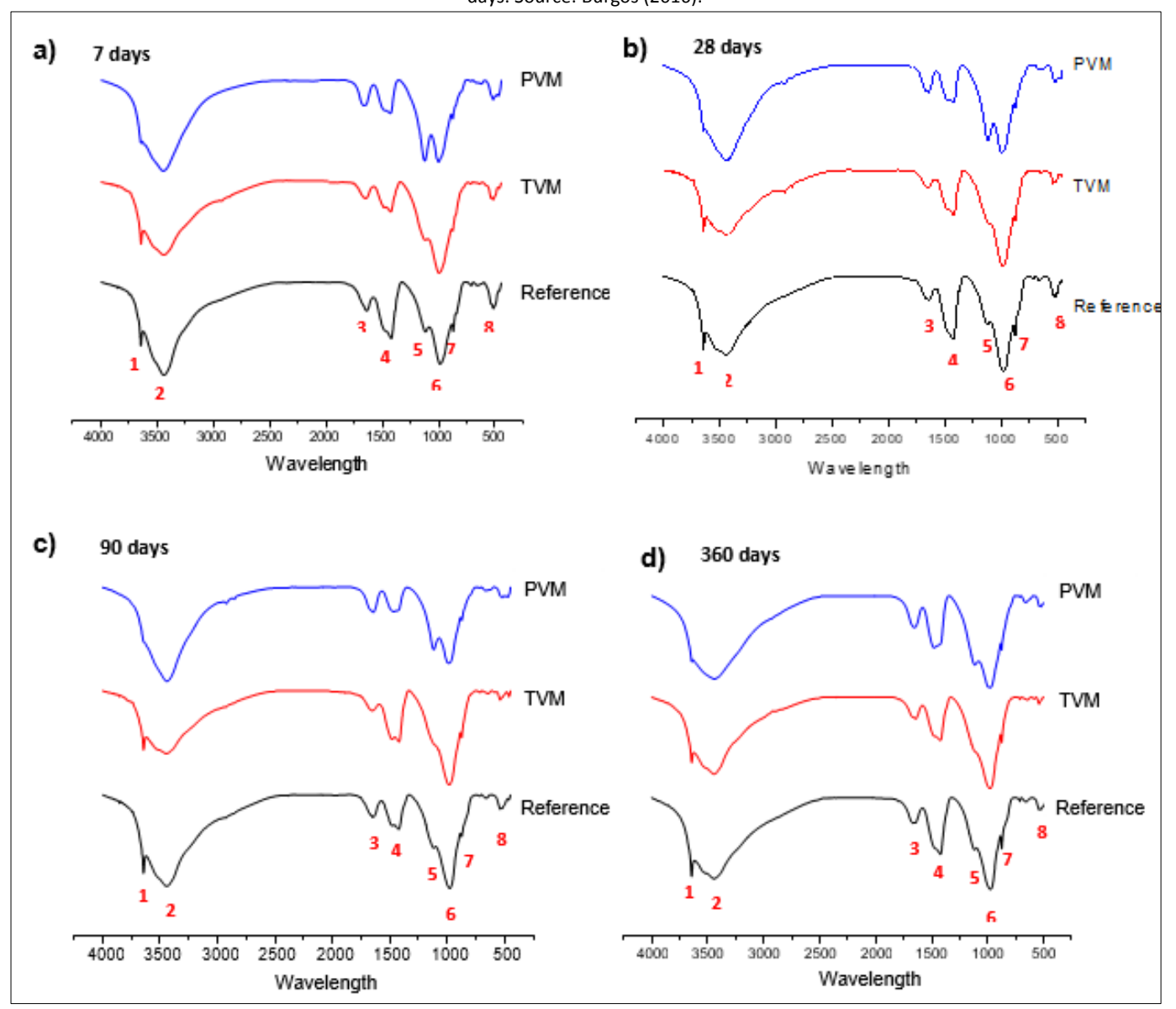

\section{Hydration study by thermogravimetric analysis (TG/DTG)}

The thermogravimetric analysis was performed using a TA Instruments SDT Q600 analyzer at a heating rate of $10^{\circ} \mathrm{C} / \mathrm{min}$ in a nitrogen atmosphere and a flow of $100 \mathrm{ml} / \mathrm{min}$ using an alumina crucible. Figure 6 shows the differential thermogravimetry (DTG) curves of the reference cement pastes and the blended cement pastes with TVM and PVM at different curing times (7, 28, 90 and 360 days). Overall, there are 6 significant peaks that increase their intensity as curing time increases.

- Peaks number 1, 2 and 3 are located in the area between 80 and $200^{\circ} \mathrm{C}$. The first peak (between 90 y $105{ }^{\circ} \mathrm{C}$ ) corresponds to the dehydration of calcium silicate hydrate (CSH) that overlaps with peak 2 (between 130 y $160{ }^{\circ} \mathrm{C}$ ) which corresponds to the dehydration of ettringite and monosulfates. The peak 3 located at approximately $180^{\circ} \mathrm{C}$, is attributed to the dehydration of calcium aluminate hydrates (CAH) and calcium aluminosilicates hydrates (CASH). 
- Peak 4, located at approximately $450^{\circ} \mathrm{C}$, corresponds to the dehydroxylation of calcium hydroxide $\left(\mathrm{Ca}(\mathrm{OH})_{2}\right)$, which is produced by the cement hydration.

- Finally, peaks 5 and 6 , located between 600 and $900^{\circ} \mathrm{C}$, correspond to the decomposition of calcium carbonate $\left(\mathrm{CaCO}_{3}\right)$. This compound may originate from the production of cement or from a slight carbonation of the sample during the processes of curing and sample preparation.

The thermogravimetric analysis confirmed the different behaviors of the volcanic materials. In the case of the blended cement with TVM, it was showed that the peaks do not change significantly with respect to the reference sample. As curing time increases, the peak locations tend to move toward higher temperatures, which suggests either that there may be different enthalpies or that because of the growth of hydration products, greater energy is needed to activate the chemical decomposition process (Esteves, 2011). With the passage of time it is possible to observe variation in peaks 1 and 2 of the blended cement pastes with TVM compared with reference cement paste, and it could be related with the dilution effect (less Portland cement when it is replace by mineral additions) in terms of the amount of formed hydrates. It is also noted that in the reference cement paste and the blended cement paste with TVM, the peak 3 (which corresponds to aluminates) tends to disappear, because it is consumed to form other phases as monosulfatos. Whereas peak 5 (which corresponds to $\mathrm{CaCO}_{3}$ ) tends to grow slightly, due to a slight carbonation of the sample during the processes of curing and sample preparation, as was commented previously.

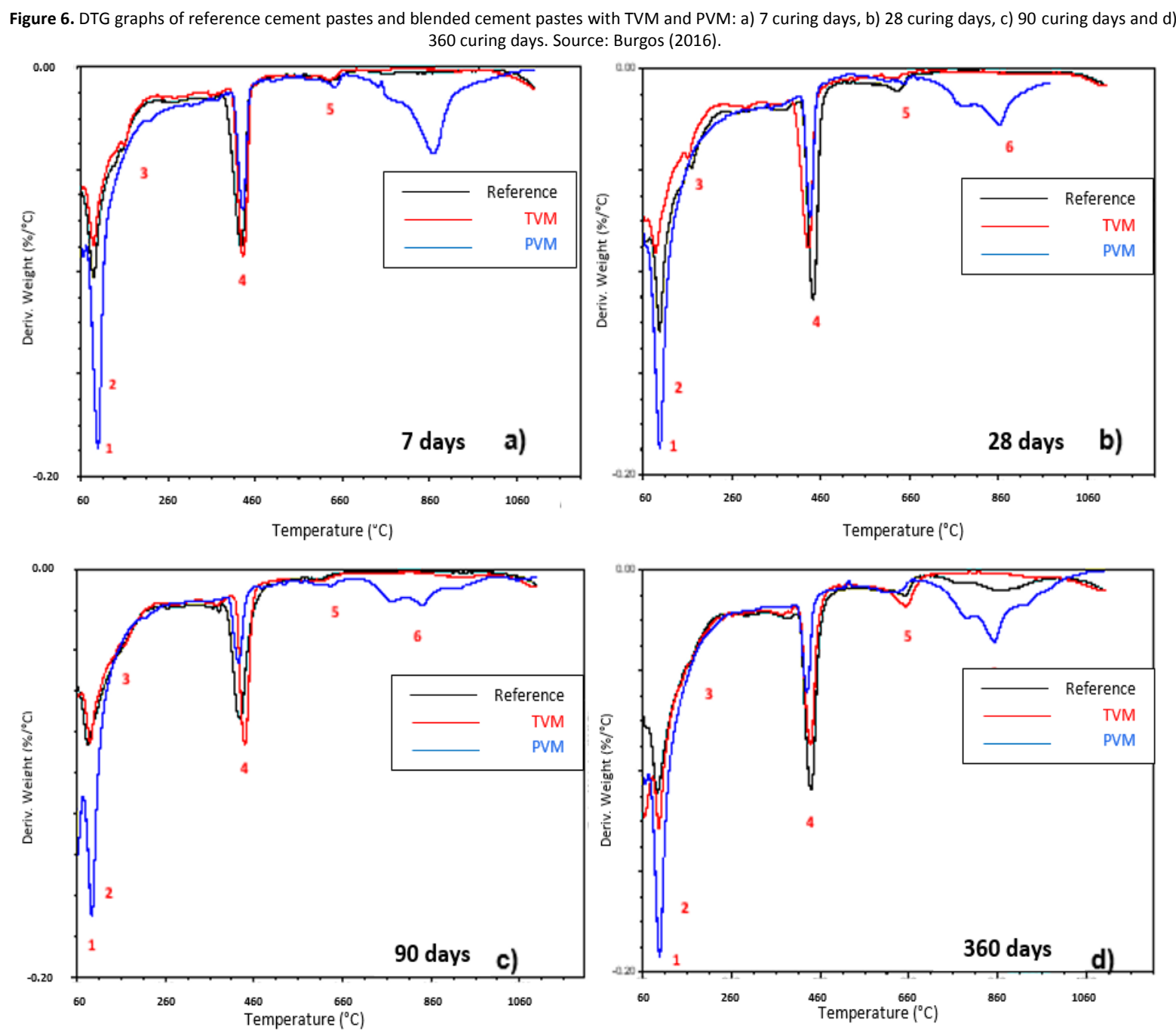

In regard to the blended cement pastes with PVM, significant differences were found with respect to the other samples. It was observed that peaks 1 and 2 (which correspond to the dehydration of CSH and ettringite, respectively) increased in intensity at early times and continued to increase as curing progressed. This behavior is due to the pozzolanic activity of the PVM, which is mainly composed of vitreous matrix that reacts with the $\mathrm{Ca}(\mathrm{OH})_{2}$ derived from the hydration of cement, thus the intensity of peak 4 diminishes considerably. In this case the pozzolanic reaction of PVM compensated the dilution effect. Additionally, the increase in peak 2 (which corresponds to the dehydration of ettringite and monosulfates) occurs because, as mentioned above, the PVM contains sulfur-derived compounds such as sulfates that 
contribute to the formation of ettringite at early ages. The peak 3 (which corresponds to aluminates) does not appear in these samples, because the PVM contains only traces of $\mathrm{Al}_{2} \mathrm{O}_{3}(0.23 \%)$ and, consequently, does not contribute to the formation of these compounds. For the samples containing PVM, a new peak 6 appears between 600 and $900^{\circ} \mathrm{C}$ that corresponds, as does peak 5, to the decomposition of $\mathrm{CaCO}_{3}$ (Traversa, lloro \& Benito, 2013), a behavior that could reveal the susceptibility to carbonation of the blended cement pastes with PVM in comparison with the reference cement paste and blended cement pastes with TVM. Such carbonation could have occurred during curing or sample preparation, as the peak intensity varies with curing time. Consequently, this important factor needs to be controlled.

\section{Pozzolanic activity measurement by TG analysis method}

The hydration process of blended cements pastes with volcanic materials is related to the pozzolanic activity of the material. This can be evaluated in terms of the maximum amount of calcium hydroxide $\mathrm{Ca}(\mathrm{OH})_{2}$ that the pozzolan can fixate and also in terms of the speed of the fixation (Mendoza \& Tobón, 2013). The percentage of fixed $\mathrm{Ca}(\mathrm{OH})_{2}$ is determined by quantifying the mass loss between 400 and $500^{\circ} \mathrm{C}$ in Figure 6 (peak that corresponds to the dehydroxylation of $\mathrm{Ca}(\mathrm{OH})_{2}$ ). The amount of $\mathrm{Ca}(\mathrm{OH})_{2}$ present in the paste was calculated and then for each age, the percentage of fixed lime was calculated from the equation 1.

$$
\text { Fixed lime } \%=\frac{\mathrm{CH}_{0}-\mathrm{CH}_{p}}{C \mathrm{H}_{0}} * 100
$$

where $(\mathrm{CH})_{0}$ is the initial amount of $\mathrm{Ca}(\mathrm{OH})_{2}$ in the reference paste and $(\mathrm{CH})_{\mathrm{p}}$ is the amount of $\mathrm{Ca}(\mathrm{OH})_{2}$ in the blended cement pastes with volcanic materials at a certain curing age. Figure 7 shows the results of fixed lime obtained for blended cement pastes with TVM and PVM. It can be observed that the samples with PVM have higher percentages of fixed lime compared with the samples with TVM for all curing ages. This behavior is due to the high pozzolanic activity of PVM compared to that of TVM. The pozzolanic reaction produced by PVM is developed from early ages of hydration; at 7 days, the lime consumption reported is $58 \%$, and this value tends to increase with curing time up to 90 days, when the reported lime consumption is $73 \%$. After this age, the lime consumption remains constant over time. In contrast, TVM showed low lime consumption, this alternative method confirmed its low pozzolanic activity compared with PVM.

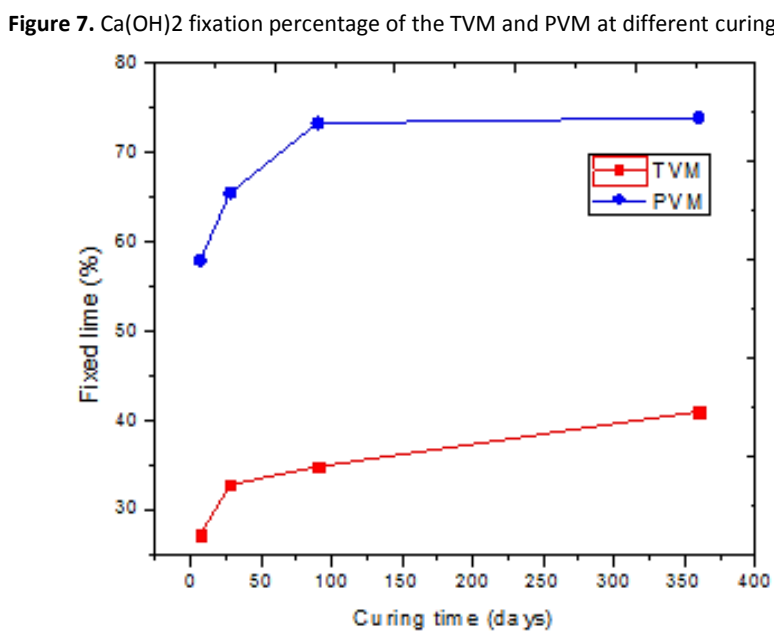

\section{Microstructural study of hydration reactions by SEM}

Figure 8 shows the SEM micrographs of the reference paste and the pastes with volcanic materials added at different curing times. The qualitative analysis of these micrographs and EDS results confirm the presence of the hydration products found in the FTIR and DTG analysis. In general, at 7 days, both the reference cement paste and the blended cement pastes with TVM and PVM exhibited small needles that indicate the formation of ettringite. However, blended cement pastes with PVM could have more ettringite formation. As was observed by FTIR and DTG analysis the sulfur compounds in PVM promoted the formation of this phase at early and advanced ages of curing. The formation of CSH gel and of calcium hydroxide $(\mathrm{CH})$ is also noted. After 28 curing days, the hydration process continues to progress. It was observed $\mathrm{CSH}$ in the reference cement paste, and some hexagonal crystals of $\mathrm{CH}$ in the blended cement pastes with TVM; in both samples the ettringite were not observed. In the case of the samples with added PVM the CSH gel predominate in the images, these could be attributed to the pozzolanic activity of the PVM generating a denser matrix. 
After 90 and 360 curing days, the hydration reactions continue and, in general, the micrographs confirms the inert nature of TVM because there was no evidence of significant changes with respect to the reference sample, even at advanced curing ages. Whereas the blended cement pastes with PVM exhibited a microstructure hexagonal laminar crystals that corresponds to monosulfates, and some crystals that correspond to delayed ettringite formation (Skalny et al., 1996). It can be concluded that the addition of PVM generates significant changes in the matrix and could be detrimental for mechanical properties and the durability of the concrete in which this pozzolanic addition is used. For this reason, it is necessary evaluate the effect of PVM in concretes exposed under aggressive environments.

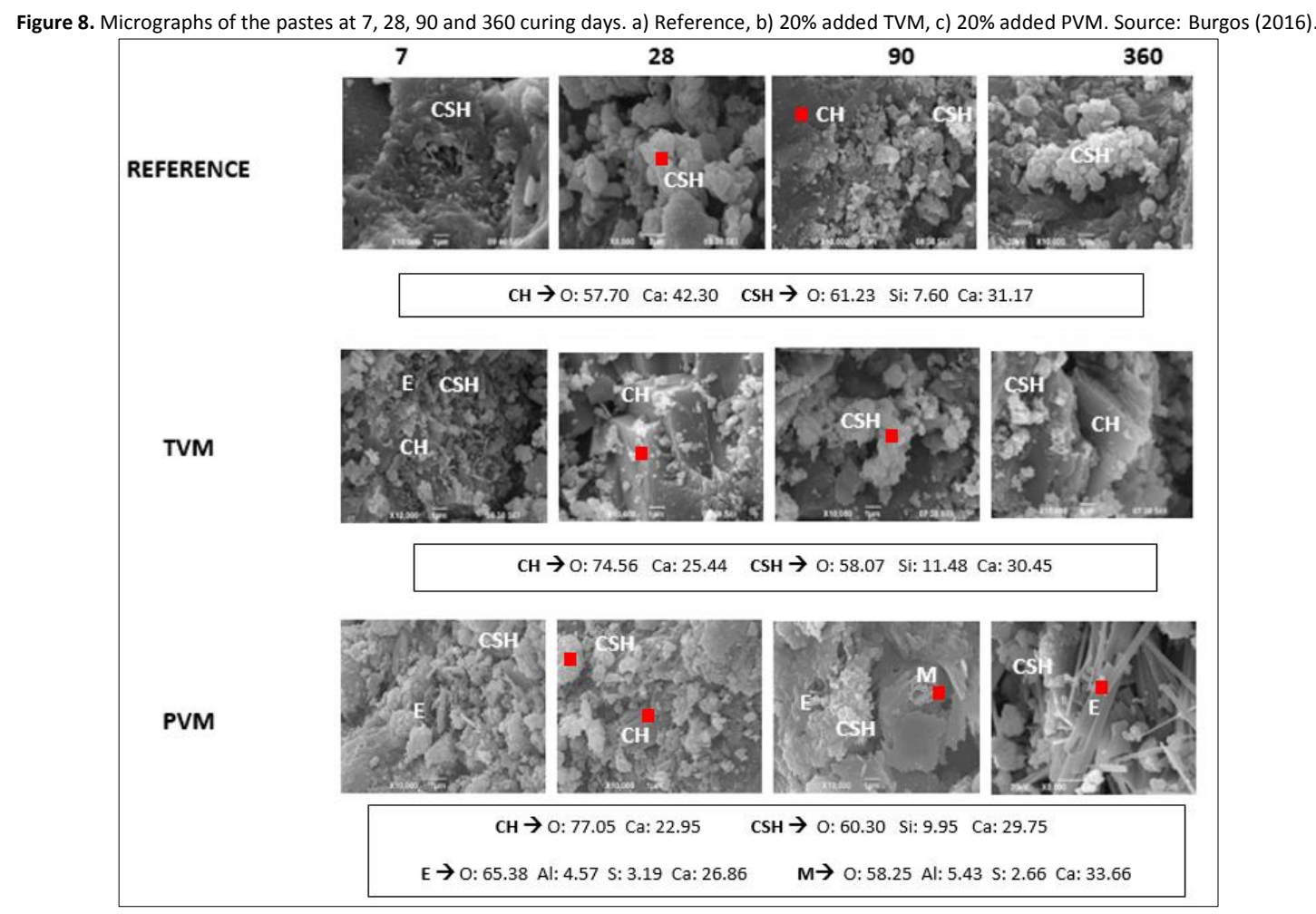

Conclusions

The incorporation of volcanic materials affects the microstructure and properties of cement pastes depending on the pozzolanic reactivity of these additions. TVM is an inert material and its filler effect promoted the formation of the hydration products very similar to reference cement pastes. In contrast, PVM had high pozzolanic reactivity for consume calcium hydroxide, so that increased formation of CSH, as was demonstrated by FTIR and TGA analysis.

The evaluation of the hydration process of the blended cement pastes with PVM indicated that the chemical and mineralogical composition of this material promotes the formation of CSH gel and ettringite. The first phase arises from the high amorphous silica content of the PVM, and the second phase arises because the chemical composition of this material contains a large amount of sulfur compounds such as sulfates that stabilize the ettringite formation to advanced ages of curing.

The evaluation of the effect of volcanic materials on the hydration of cement pastes demonstrates that following an appropriated methodology to evaluate these materials, it is possible to define which could be more suitable as a partial substitute of Portland cement for applications in the production of mortars and concretes for the construction industry.

References

ASTM, American Society for Testing and Materials (2012). ASTM C618/C618-12a Standard Specification for Coal Fly Ash and Raw or Calcined Natural Pozzolan for Use in Concrete. West Conshohocken, PA: ASTM.

ASTM, American Society for Testing and Materials (2014). ASTM C230/C230M-14 Standard Specification for Flow Table for Use in Tests of Hydraulic Cement. West Conshohocken, PA: ASTM.

Balog, A.-A., Cobîrzan, N., Aciu, C., \& lluţiu-Varvara, D. A. (2014). Valorification of Volcanic Tuff in Constructions and Materials Manufacturing Industry. Procedia Technology, 12, 323-328. https://doi.org/10.1016/j.protcy.2013.12.493 
Bhat, P. A., \& Debnath, N. C. (2011). Theoretical and experimental study of structures and properties of cement paste: The nanostructural aspects of C-S-H. Journal of Physics and Chemistry of Solids, 72(8), 920-933. https://doi.org/10.1016/j.jpcs.2011.05.001

Bonavetti, V. L., \& Rahhal, V. F. (2006). Interacción de Adiciones Minerales en Pastas de Cemento. Revista de la Construcción, 5(2), 33-41.

Burgos, D. M., Cardona, L. M., \& Delvasto, S. (2014). Estudio de dos materiales volcánicos y efecto del tipo de molienda en su reactividad. Revista Ingeniería de Construcción, 29(2), 159-174. https://doi.org/10.4067/S0718-50732014000200003

Burgos, D. M., Cardona Ramírez, L. M., Gordillo Suárez, M., \& Delvasto Arjona, S. (2015). Evaluation and pozzolanic effects of the puracé volcanic material. Revista EIA, (23), 83-93. Retrieved from http://www.scielo.org.co/scielo.php?script=sci_arttext\&pid=S1794$12372015000100008 \& \operatorname{lng}=e n \& n r m=i s o \&$ thng=es

Burgos, D.M. (2016). Concreto autocompactante adicionado con material volcánico. Ph.D thesis, Universidad del Valle, Cali, Colombia.

Çavdar, A., \& Yetgin, Ş. (2007). Availability of tuffs from northeast of Turkey as natural pozzolan on cement, some chemical and mechanical relationships. Construction and Building Materials, 21(12), 2066-2071. https://doi.org/10.1016/j.conbuildmat.2006.05.034

Delgado, A. (2006). Valorización de rocas volcánicas como adiciones puzolánicas para fabricar cementos - Documents. Universidad de Castilla-La Mancha, Departamento de Ingeniería Química Facultad de Ciencias Químicas. Retrieved from http://myslide.es/documents/valorizacion-derocas-volcanicas-como-adiciones-puzolanicas-para-fabricar-cementos.html

Esteves, L. P. (2011). On the hydration of water-entrained cement-silica systems: Combined SEM, XRD and thermal analysis in cement pastes. Thermochimica Acta, 518(1-2), 27-35. https://doi.org/10.1016/j.tca.2011.02.003

Hamidi, M., Kacimi, L., Cyr, M., \& Clastres, P. (2013). Evaluation and improvement of pozzolanic activity of andesite for its use in eco-efficient cement. Construction and Building Materials, 47, 1268-1277. https://doi.org/10.1016/j.conbuildmat.2013.06.013

Heikal, M., Abd El Aleem, S., \& Morsi, W. M. (2013). Characteristics of blended cements containing nano-silica. HBRC Journal, 9(3), 243-255. https://doi.org/10.1016/j.hbrcj.2013.09.001

Hidalgo, A., Petit, S., Domingo, C., Alonso, C., \& Andrade, C. (2007). Microstructural characterization of leaching effects in cement pastes due to neutralisation of their alkaline nature. Cement and Concrete Research, 37(1), 63-70. https://doi.org/10.1016/j.cemconres.2006.10.002

Hossain, K. (2005). Volcanic ash and pumice as cement additives: pozzolanic, alkali-silica reaction and autoclave expansion characteristics. Cement and Concrete Research, 35(6), 1141-1144. https://doi.org/10.1016/j.cemconres.2004.09.025

Kirk, S., \& Zuleta, R. (2000). A study of the volcanic ash originating from Mount Pinatubo, Philippines. Public Works. Philippines. Retrieved from http://www.dfid.gov.uk/R4D/Output/5197/Default.aspx

Massazza, F. (1993). Pozzolanic cements. Cement and Concrete Composites, 15(4), 185-214. https://doi.org/10.1016/0958-9465(93)90023-3

Mendoza, O., \& Tobón, J. I. (2013). An alternative thermal method for identification of pozzolanic activity in Ca(OH)2/pozzolan pastes. Journal of Thermal Analysis and Calorimetry, 114(2), 589-596. https://doi.org/10.1007/s10973-013-2973-y

Pavlidou, E. (2011). Systematic analysis of natural pozzolans from Greece suitable for repair mortars. Journal of Thermal Analysis and Calorimetry, 108(2), 671-675. https://doi.org/10.1007/s10973-011-2039-y

Prado, B., Duwig, C., Hidalgo, C., Gómez, D., Yee, H., Prat, C., Esteves, M. \& Etchevers, J. (2007). Characterization, functioning and classification of two volcanic soil profiles under different land uses in Central Mexico. Geoderma, 139(3-4), 300-313. https://doi.org/10.1016/J.GEODERMA.2007.02.008

Puertas, F., Goñi, S., Hernández, M. S., Varga, C., \& Guerrero, A. (2012). Comparative study of accelerated decalcification process among C3S, grey and white cement pastes. Cement and Concrete Composites, 34(3), 384-391. https://doi.org/10.1016/j.cemconcomp.2011.11.002

Rahhal, V., \& Talero, R. (2009). Fast physics-chemical and calorimetric characterization of natural pozzolans and other aspects. Journal of Thermal Analysis and Calorimetry, 99(2), 479-486. https://doi.org/10.1007/s10973-009-0016-5

Roverato, M., Capra, L., \& Sulpizio, R. (2013). First evidence of hydromagmatism at Colima volcano (Mexico). Journal of Volcanology and Geothermal Research (Vol. 249). https://doi.org/10.1016/j.jvolgeores.2012.10.012

Siddique, R. (2011). Effect of volcanic ash on the properties of cement paste and mortar. Resources, Conservation and Recycling, 56(1), 66-70. https://doi.org/10.1016/j.resconrec.2011.09.005

Skalny, J., Johansen, V., Thaulow, N., \& Palomo, A. (1996). DEF: Una forma de ataque por sulfatos. Materiales de Construcción, 46(244), 5-29. https://doi.org/10.3989/mc.1996.v46.i244.519

Traversa, L., Iloro, F., \& Benito, D. (2013). Determinación mediante ensayos térmicos del $\mathrm{CO}_{2}$ absorbido por morteros de cemento. Ciencia y Tecnología de los Materiales, (3), 333-341. Retrieved from http://docplayer.es/10439263-Determinacion-mediante-ensayos-termicos-del-co-2-absorbidopor-morteros-de-cemento-absorbed-by-cement-mortars.html

Trezza, M., \& Lavat, A. (2001). Analysis of the system $3 \mathrm{CaO} \cdot \mathrm{Al}_{2} \mathrm{O}_{3}-\mathrm{CaSO}_{4} \cdot 2 \mathrm{H}_{2} \mathrm{O}-\mathrm{CaCO}{ }_{3}-\mathrm{H}_{2} \mathrm{O}$ by FT-IR spectroscopy. Cement and Concrete Research, 31(6), 869-872. https://doi.org/10.1016/S0008-8846(01)00502-6

Uzal, B., \& Turanli, L. (2003). Studies on blended cements containing a high volume of natural pozzolans. Cement and Concrete Research, 33(11), 1777-1781. https://doi.org/10.1016/S0008-8846(03)00173-X

Valdez, P., Das, T., \& Rivera, R. (2004). Evaluación de la velocidad de hidratación en sistemas puzolanas naturales-portlandita. Ciencia UANL, 7(2), 190-195. Retrieved from http://eprints.uanl.mx/606/ 